\title{
HET RECHT EN DE TAAK VAN DE BEZWAARDE BROEDER OF KERKERAAD
}

\author{
De positie van de bezwaarde in een conflict volgens art. 31 \\ of $46 \mathrm{~K} .0$.
}

Indien een kerklid of kerkeraad bezwaard is over een uitspraak van een kerkelijke vergadering omdat deze uitspraak naar zijn oordeel in strijd is met het Woord van God of de artikelen van de Kerkenorde, zal hij volgens art. 31 K.O. appèl of volgens art. 46 K.O. revisie dienen in te stellen.

Welke is nu de positie van de bezwaarde in zulk een conflict van botsende gewetens van hem en de kerkelijke vergadering?

Deze wordt bepaald door het Woord van God en de Kerkenorde, waarbij vooral artikel 31 van belang is. Artikel 31 handelt over beroep en rechtskracht van besluiten van kerkelijke vergaderingen. Een juiste uitlegging hiervan zal helpen om de gestelde vraag op de rechte wijze te beantwoorden.

\section{Juiste uitlegging van art. 31 K.0. volgens Afrikaanse en La- tijnse teksten}

In de Afrikaanse tekst luidt het eerste gedeelte: „Wat op 'n kerklike vergadering met meerderheid van stemme besluit is, moet as vas en bindend beskou word tensy bewys word dat dit in stryd is met Gods Woord of die artikels van die Kerkorde".

De Latijnse tekst van Dordrecht 1619 luidt: „Quod vero plurium suffragiis erit probatum, id ratum habebitur, nisi Verbo Dei, aut etiam articulis, a Synodo generali constitutis, donec alia Synodo generali mutentur, adversari ostendatur". ${ }^{1}$

Het valt op dat de Latijnse tekst het futurum en niet de imperatief gebruikt zoals in de afrikaanse tekst het geval is. De eerste tekst omschrijft dus niet een moeten, maar een zullen, constaterende wat het geval zal zijn, namelijk dat een besluit geldig zal zijn; of ongeldig ingeval dit in strijd is met Gods Woord of de K.O. Deze tweede mogelijkheid van ongeldigheid (is: nietigheid), ligt opgesloten in het gebruik van ,nisi" = ,tensy" = indien niet. In onderscheiding met "totdat" = „donec" — wat in de latijnse tekst in ander verband gebruikt wordt (doch in de afrikaanse tekst als overbodig weggelaten werd) staat in art. 31 K.O. dus niet dat besluiten van kerkelijke vergaderingen geldig zijn totdat $\mathrm{zij}$ worden herroepen, terzijdegesteld, ingetrokken of vernietigd. In dit geval zou men van „vernietigbare" besluiten kunnen spreken in onderscheiding van - „ab inito" - „nietige" of ongeldige besluiten. Besluiten in strijd met Gods Woord zijn nooit geldig, al kunnen zij de uiterlijke schijn van geldigheid hebben.

Dit is kennelijk ook de opvatting van de Algemene Synode van die Gereformeerde Kerk in Suid-Afrika volgens Handelinge 1939, 
art. 135. Deze bepaalde als bedoeling van de woorden ,tensy..." in art. 31 K.O.:

a. kerkelijke besluiten zijn geldig tenzij zij in strijd zijn met het Woord van God;

b. in concrete gevallen mogen kerkelijke besluiten niet ingaan tegen de artikelen van de kerkorde, zolang die artikelen niet veranderd zijn.

Deze opvatting steunt ook op art. 7 Nederlandse Geloofsbelijdenis, waar staat: „Men mag ook gener mensen schriften, hoe heilig zij geweest zijn, gelijkstellen met de Goddelijke Schrifturen, noch de gewoonte met de waarheid Gods..." enz.

Tenslotte wordt in de latijnse tekst het werkwoord ostendare gebruikt, dat in het afrikaans door bewys is vertaald. Het meest gebruikte latijn voor bewijzen in rechte schijnt probare, niet ostendare te zijn. „Ostendare" heeft eerder de betekenis van evident zijn, duidelijk blijken eerder dan van bewijslevering met inachtneming van procesrechtelijke regels.

In het uitzonderingsgeval van het tensy behoeft derhalve de kerkelijke vergadering niet of nog niet tot overeenstemming met de bezwaarde te zijn gekomen dat deze het bewijs reeds geleverd heeft alvorens de bezwaarde volgens geweten mag handelen. De tekst van art. 31 K.O., vooral de woorden nisi... ostendatur dwingen niet tot een andere opvatting.

\section{De kerkelijke orde gedurende de tijd van appèl in behandeling}

Wat komt er in de hier vermelde uitlegging echter van de kerkelijke orde terecht gedurende de tijd dat een appèl of revisie in behandeling is? Is er hieromtrent geen kerkelijke regeling?

Ten aanzien van opvattingen van ambtsdragers omtrent de gereformeerde leer geldt hiervoor het ondertekeningsformulier. Daarin hebben zij beloofd om hul afwijkende gevoelens niet openlijk te propageren, maar deze aan de kerkelijke vergaderingen voor te leggen. Overtreding van deze regel brengt voor de predikanten volgens de oorspronkelijke tekst van dit formulier „op poene dat wij hiertegen doende ipso facto van onze diensten gesuspendeerd zullen zijn" vanzelf schorsing mee. Volgens deze tekst wordt zulk een predikant niet geschorst volgens art. 79 K.O., maar door het enkele feit van de overtreding heeft hij zichzelf geschorst. De kerkeraad en meerdere vergaderingen kunnen dus volstaan met te constateren dat hij geschorst is.

In het afrikaanse ondertekeningsformulier is deze gestrengheid verzacht. Daarin is sprake van „op straf, as ons hierteen handel, dat ons metterdaad van ons dienste geskors sal word". Dit veronderstelt meer dan een constatering, dat de predikant zichzelf geschorst heeft, maar een schorsingsdaad langs de weg van art. 79 en art. 80 K.O. Het woord metterdaad, hetgeen ipso facto betekent, maakt deze zinsnede overigens tot een contradictie.

In beide genoemde redacties van het ondertekeningsformulier is er niettemin niet van een gewetensbinding sprake; deze zou in 
strijd zijn o.a. met art. 7 Ned. Geloofsbelijdenis. Maar hangende zulk een verschil in inzicht in de leer der Schriften zullen de predikanten en volgens de afrikaanse formulieren ook de andere ambtsdragers, de eenheid der kerk dienen, niet door te zwijgen maar door hun bezwaren in te dienen ter plaatse waar het behoort. Het formulier verbiedt een onschriftuurlike ordeverstorende dialoog over de waarheden Gods, maar schrijft coöperatie voor in het onderzoek daarnaar. De bezwaarde kan zich vergissen door een verkeerde uitlegging te goeder trouw van het Woord van God. Hij kan zich dan laten overtuigen door de kerkelijke vergaderingen. Want al heeft de bezwaarde gewetensvrijheid; dit betekent niet dat deze vrijheid de binding aan Gods Woord kan opheffen. De kerkelijke vergaderingen kunnen dit evenmin.

\section{De positie van de bezwaarde}

Welke is nu, buiten het bijzondere hier gestelde geval van kerkelijke ambtsdragers, die bedenkingen tegen de gereformeerde leer hebben, de algemene regeling van de positie van elk bezwaard kerklid en kerkeraad, niet alleen in leer- maar ook in tuchtkwesties? Het antwoord moet te vinden zijn in Schrift, Belijdenis en K.O.

Bij de beantwoording gaan we ervan uit, dat de K.O. geen zelfstandige grootheid is, maar dat zij onderworpen is aan Schrift en Belijdenis. De Schrift bevat de volmaakte wet des Heren, zodat er in de kerk geen ruimte is voor noodrecht en wij dus ook niet te spoedig mogen klagen over onvolledigheid van de K.O.

Omdat de Schrift leert, dat in de kerk niets kracht heeft en mag hebben wat tegen haar ingaat, moet de mogelijkheid altijd verondersteld worden dat besluiten van kerkelijke vergaderingen nietig zijn. Maar evenzeer leert de Schrift dat de kerk een pilaar en vastigheid der waarheid is. De kerk moet dus door Gods Geest ook in staat zijn om de waarheid te vinden en te formuleren tegen ketterijen. Daaraan danken we onze belijdenisgeschriften.

De Heilige Schrift regelt nu ook de ethiek en de techniek van het bezwaard-zijn tegen kerkelijke besluiten. De wijze waarop dit behoort te gebeuren vond ik prachtig uiteengezet in een rapport, dat werd ingediend op de synode van Bunschoten-Spakenburg in 1958. ${ }^{2}$ Ik citeer daaruit het volgende:

"In artikel $31 \mathrm{~K} . \mathrm{O}$. is overeengekomen dat voor vast en bondig gehouden zal worden hetgeen ter kerkelijke vergaderingen met de meeste stemmen is besloten.

Doch deze afspraak verplicht niet, in geval zodanig besluit bewezen wordt te strijden tegen Gods Woord of de K.O.

In de kerk kán immers nooit onderwerping worden geëist aan wat niet uit God is. Het gezag van kerkelijke uitspraken, juist als kerkelijke uitspraken, zal op de autoriteit van Gods Woord moeten steunen.

Dat Woord bindt, tot in het geweten, maar maakt tevens dagelijks vrij van alle mensen-heerschappij. Geen kerkelijke vergadering kan treden tussen Christus en de lidmaten Zijner kerk, geen kerkelijk besluit kan die lidmaten ooit dwingen de weg van Gods Woord en de Gereformeerde K.O. te verlaten. 
Maar evenmin dwingt een kerkelijk besluit, dat verkeerd is te „achten, een lidmaat van Christus kerk „terwille van de orde" het verband te verlaten. Hij mag op de weg van Woord en K.O. blijven wandelen. Hij mag zich vrijmaken en vrij weten van zondige besluiten. En tegelijk mag hij de bewijsvoering voor de onjuistheden overleggen aan de kerkelijke vergaderingen. Zo wil art. 31 K.O. de weg wijzen om het samenleven en kerkverband te bewaren, onder beslag van Gods gemeenschapstichtend en gemeenschapherstellende Woord.

$\mathrm{Nu}$ is in artikel 31 K.O. evenwel geen voorschrift te vinden omtrent de "practische houding", die door een "bezwaarde” dient te worden ingenomen. Hij heeft het recht in appè te gaan, en intussen "niet voor vast en bondig te houden". Hij staat "vrij", in christelijke vrijheid, tegenover het betwiste besluit.

Maar het practisch effect daarvan onder de mensen wordt voor deze „bezwaarden” door de K.O. niet geregeld. Zulke regeling zou ook zeer gevaarlijk zijn, omdat voorschriften omtrent het gedrag in de tijd van bezwaarnis juist de vrijheid principieel zouden kunnen aantasten. Ook zal nimmer een reglement kunnen voorzien in de veelheid en gevarieerdheid der situaties, die hier mogelijk zijn.

Dat aldus de ethiek en techniek van het bezwaard zijn niet geregeld zijn in de K.O. mag een bewijs te meer zijn van het gereformeerde karakter van de K.O. die immers het tegendeel van een het Woord Gods verduisterende reglementenbundel wil wezen, en principieel weigert door een veelheid van menselijke, disciplinaire voorschriften de N.T.ische rijkdom van de kerk haar vrijheid in Christus - krachteloos te maken.

Dat wil niet zeggen, dat de ethiek en techniek van het bezwaard zijn niet geregeld zijn. Die zijn niet in de K.O. geregeld. Doch wel in de Heilige Schrift. Niet bij apart voorschrift, doch in heel de Schrift, die tot alle goed werk wijs maakt. Gods Woord is een licht, en Gods Wet geeft verstand juist ook terzake van het gebruik van de door Christus verleende vrijheid. Daarom is de tijd van bezwaarnis, waarin een bezwaarde zich „vrij” weet van een hem z.i. ten onrechte opgelegd besluit, vol verantwoordelijkheid, juist voor die bezwaarde. Hij zal nu als kérk-mens openbaar moeten worden, want wie zich beroept op de vrijheid die in Christus is, zal vervolgens moeten tonen, dat hij "wijs" is die vrijheid te benutten, ook zonder dat zijn weg duidelijk is afgebakend door kerkelijke afspraken en gedragsregels.

Hij zal moeten tonen, dat hij - zich ,vrij” wetende van een besluit zich schuldenaar weet jegens hen, die besloten en de kerk van de weg van het Woord en de K.O. dreigden af te voeren. Want de bezwaarde beroept zich op artikel 31 K.O. Hij wil dus niet á van de weg van het Woord en K.O.

Welnu, als een kerklid zich krachtens zijn verantwoordelijkheid voor God vrij weet onder de mensen, dan zal deze christelijke vrijheid naar art. 31 K.O. het bewijs van haar christelijkheid in het wijs en stichtelijk gebruik leveren en te leveren hebben. Datzelfde Woord Gods, waarop hij zich beriep, zal hem de weg in de bezwaarnis wijzen.

Daarom zal hij in zijn praktische houding de kerk zoeken te stichten, de broederschap zoeken te bewaren, het conflict zo klein mogelijk trachten te houden, geen doorgang geven aan de juist in conflict-situaties zo gevaarlijke driften van het vlees, zich onthouden van elke „prikkel tot zonde" tegenover de vergadering, die verongelijkte. 
Evenzeer zal hij in al zijn handelen zich naar de klare uitspraken van de Schrift richten, want daarop beriep hij zich immers? Ook zal hij de onklaarheid van de situatie trachten op te lossen door te meer zich te houden aan de orde, die Christus stelde voor Zijn Kerk. Zodat artikel $31 \mathrm{~K} . O$. bepaald geen vrijbrief geeft voor de „vrije” conscientie, met haar niet te controleren en te verifiëren inspraken. Op het niveau van het wórd zal getwist worden, want art. 31 K.O. waakt voor het uitsluitend gezag van Gods gemeenskapstichtend Woord, niet voor "de" individuele vrije conscientie.

Zo is dan met name in Galaten 5, 2 Tim. 2 : 24 vv., Titus $1: 7$ de „ethiek van het bezwaard zijn "geregeld”. Bezwaarden, die „vrucht” des Geestes tonen, in hun niet voor vast en bondig houden - tegen de zodanigen is det wet nie, noch die van God, noch die van mensen (Gal. 5 : 23)".

In het bewuste geval ging het om een zendeling, die na geschorst te zijn in zijn ambt, niettemin met een beroep op het ,tenzij" in art. 31 K.O. naar zijn zendingsveld was teruggekeerd. De zendeling kwam in beroep tegen het uitdrukkelijke verbod om naar het zendingsveld terug te keren. De synode van Enschede 1955-1956 had uitgesproken dat de kerkeraad gehouden was aan de zendeling te berichten dat hij hem in zijn ambt weer begeerde te erkennen en te ontvangen en dat de zendeling gehouden was aan de kerkeraad te berichten dat hij hem weer begeert te erkennen en te aanvaarden als raad van de kerk van Jezus Christus. Een bemiddelende ${ }^{3}$ uitspraak dus, waarbij de schorsing en afzetting voor ongeldig werd gehouden.

De synode van 1958 wees echter de stelling van de zendeling af (dat hij door deze ongeldigheid van de schorsing zijn eigen weg mocht volgen, onafhankelijk van de kerkeraad) op de volgende gronden, die op het aangehaalde rapport berusten:

1. dat in artikel 31 K.O. de door Gods Woord verleende vrijheid eventueel plicht is erkend, een besluit dat bewezen wordt te strijden met Gods Woord of de Kerkenordening, niet voor vast en bondig te houden;

2. dat bij het erkennen van deze plicht, respec. vrijheid geen onderscheid dient te worden gemaakt tussen uitspraken van een kerkeraad en die van een meerdere vergadering;

3. dat art. 31 K.O. geen voorschrift bevat omtrent de gedragslijn, welke door een bezwaarde in de tijd van zijn bezwaarnis dient te worden gevolgd;

4. dat deze gedragslijn naar uitwijzen van Gods Woord tot stichting der kerk in christelijke vrijheid dient te worden bepaald (1 Kor. $10: 23,24$; Rom. $14: 19,20$ );

5. dat de gedragingen van een bezwaarde in de tijd van zijn bezwaarnis naar het in 4 gestelde beoordeeld dienen te worden.

\section{De bezwaarde behoeft zich gedurende appèl niet te gedragen alsof het besluit geldig was}

Ik zou hieraan willen toevoegen, dat op het voetspoor van wereldlijk recht niet mag worden aangenomen, dat indien een bezwaarde zijn christelijke vrijheid zo uitoefent, dat hij zich tijdens de behandeling van het appèl gedraagt alsof het besluit geldig was, daaruit niet tot een berusting in het besluit mag worden geconcludeerd. 
De opvatting, dat in geval van bezwaar de bezwaarde gebonden is totdat de meerdere vergadering anders heeft beslist, is in strijd met de gereformeerde opvatting omtrent kerkverband en leidt tot hiërarchie.

Een meerdere vergadering is geen hogere kerkelijke vergadering, maar een vergadering waar meer kerken door haar afgevaardigden tegenwoordig zijn. Dit blijkt ondubbelzinnig uit de tekst van artt. $33,41,47$ en 50 K.O. Deze afgevaardigden zijn in hun last en volmacht volgens art. 33 en art. 41 K.O. gebonden aan Gods Woord, de Belijdenissen der Kerk en de Kerkorde (zie blz. 112 Kerkorde Gereformeerde Kerk in Suid-Afrika, 1968). In dezelfde lastbrief verbindt de kerkeraad zich als lastgever om alle besluiten van de meerdere vergadering die daarmede niet in strijd zijn, als bindend en vast te beschouwen en hen getrouw te helpen naleven en uitvoeren. Deze stipulatie berust woordelijk op art. $31 \mathrm{~K} .0$. en houdt impliciet in dat besluiten in strijd met Gods Woord niet als geldig mogen worden beschouwd.

\section{Mandare behoeft geen bijzondere daad van ratificatie}

Het woord mandare is een contractie van in manum dare. De lastgever legt iets in die hand van de ander, vertrouwt hem iets toe. Dit duidt beter dan het moderne woord lastgeving aan wat mandaat in oorsprong was: een vertrouwensverhouding tussen twee vrienden. Amicitia vormt de basis van het mandaat, en dit is ook bepalend voor de rechtsgevolgen... Vrijwel alle belangen konden ter behartiging aan een lasthebber worden toevertrouwd. ${ }^{4}$

Krachtens de lastgevingsovereenkomst is een lastgever onmiddellik gebonden aan de daad van de lasthebber binnen de grenzen van zijn opdracht verricht. 5 Een bijzondere daad van bekrachtiging, ook wel ratificatie genoemd - zoals bij verdragen tussen staten gebruikelijk - behoeft daar niet aan toegevoegd te worden. ${ }^{b}$

Wel heeft de lastgevende kerk het recht en de plicht om te toetsen of de meerdere vergadering binnen haar volmacht is gebleven. Hetzelfde recht heeft elk kerklid volgens art. $31 \mathrm{~K} .0$. ten opzichte van besluiten van kerkelijke vergaderingen. ${ }^{7}$ Indien een kerkeraad besluiten die door die vergaderingen ultra vires zijn genomen en dus ongeldig zijn, toch zou uitvoeren, kan dit als ratificatie beschouwd worden, d.w.z. een geldig maken van ongeldige besluiten. Indien het daarbij slechts om middelmatige zaken gaat, is dat niet erg. Maar als het om de grondslagen van de kerk gaat en niet een incidenteel geval betreft kan dit een gereglementeerde deformatie van de kerk tot gevolg hebben. Hiertegen is meestal zelfs bij de wereldlijke rechtbanken geen hulp te verkrijgen, omdat deze zich in zaken van geloof onbevoegd verklaren. De kerkeraden moeten dus de wacht betrekken tegen overschrijding van de last door de meerdere vergaderingen en moeten daartoe van hun toetsingsrecht gebruik maken. ${ }^{8}$ Zoals reeds gesteld houdt dit slechts in de constatering of de besluiten geldig dan wel ongeldig zijn. In art. 31 K.O. is daarom sprake van ratum habere, niet van ratificare. Erkenning van een ratificatierecht kan leiden tot independentisme. 


\section{Geen executie van een nietig besluit}

Aangezien een nietig besluit strikt genomen geen besluit is, want voor het bestaan van een besluit is geldigheid een onmisbaar element, is het onjuist om reeds over executie van besluiten te spreken, ${ }^{9}$ voordat toetsing heeft plaats gevonden. Dit kan nieuwe verwarring doen ontstaan, b.v.

1. alsof een besluit de facto geldig zou zijn, maar wegens gemis aan de jure binding niet of nog niet zou behoeven te worden uitgevoerd; 10 of

2. alsof een besluit de jure geldig is, maar de facto nog niet zou behoeven te worden uitgevoerd.11

Al de juristerij omtrent de jure en de facto binding, die in het volkenrecht vele strijdvragen oproept, kan uit ons gereformeerde woordenboek verdwijnen, indien wij ons bij een consequente toepassing van het beginsel houden, dat alle besluiten in strijd met Gods Woord nietig zijn (die voor Gods aangezicht niet kunnen bestaan, vgl. Psalm $33: 10,11$ ). Zij mogen dus ook niet worden uitgevoerd.

Zoals reeds gesteld heeft de bezwaarde, die zich niet conformeert, de appèlweg te bewandelen. Hij gaat aan de meerdere vergadering het bewys voorleggen dat hij voor zichzelf reeds geleverd heeft ${ }^{12}$ en vraagt deze vergadering hem in het gelijk te stellen door de nietigheid van de betrokken besluiten te constateren. Vanzelfsprekend moet hij zich in broederlijke gezindheid ook openstellen voor de mogelijkheid dat hij geheel of ten dele ongelijk heeft, waartoe hij gelegenheid moet geven om zich te laten overtuigen.

Door niet in appèl te gaan wordt het betrokken besluit echter niet vanzelf geldig, indien het overigens al nietig zou zijn. ${ }^{13}$ Het is immers denkbaar, dat de appèlweg onbegaanbaar is, bv. door wanorde in het kerkverband of door oorlogsomstandigheden.

\section{Geestelijke aspecten van bezwaard-zijn}

De geestelijke aspecten van het bezwaard-zijn zijn waarschijnlijk meestal nog belangrijker dan de kerkelijke regels. Ik sluit daarom dit opstel af met de volgende aanhaling uit een kerkblad:14

Het schrijven van een bezwaarschrift kan zijn een "vrucht des Geestes". Want de Heilige Geest heeft zich een woning gemaakt in de gemeente van Christus, opdat het ganse volk „profeteren" zou.

Kerk-zaken zijn niet zonder meer kerkeraadszaken; de kerk is de vergadering der gelovigen. Zó zal elke kerkelijke vergadering de handtekening onder het bezwaarschrift hebben te eren. Dit is het principiële "recht" van de bezwaarde, zijn van God ontvangen "rechtspersoonlijkheid". Het kan in dagen van heftige geestelijke worsteling een weldaad zijn, wanneer velen uit de gemeente zich tot de kerkeraad wenden, om daaraan kenbaar te maken het inzicht, dat zij verkregen in de tijd en in de eisen des Heeren voor die tijden. Wanneer reeds een kleine stad door de wijsheid van een arme man verlost kan worden van de omsingeling door een groot koning - hoeveel te meer zal de stad verlost kunnen worden door de wijsheid van een der lidmaten van Gods Pinksterkerk?

Het is te hopen, dat geen kerkelijke vergadering in zo 'n situatie te ver- 
gelijken zou zijn met cen oud en zot koning, die niet meer weet van vermaand te worden door een arme wijze jongeling, die profeteert. Daarom is het een ergerlijke zaak, wanneer een bezwaarde reeds als zodanig en bij voorbaat in de publieke opinie op de kerkelijke vergadering gediskwalificeerd is, omdat hij het waagt bezwaard te zijn. Zodanige diskwalificatie wordt niet verontschuldigd door een verwijzing naar de vermoeidheid van een vergadering en kan een zeer ernstig blijk zijn van bittere hiërarchische zelfvoldaanheid van de ambtsdragers.

En de God, Die zijn volk heeft ingescherpt om te staan naar de gerechtigheid, ja: daarnaar te jagen (vgl. Deut. 16:20), wordt bedroefd, zovaak dit „recht der bezwaarden" wordt verkort, op de officiële wijze van niets-zeggende kerkelijke-besluiten-volzinnen...

Een bezwaarde dient serieus genomen te worden, als lidmaat van Christus dient hij bejegend te worden.

Die bejegening, waartoe het geloof de ambtsdragers steeds opnieuw dringen moet, zal uit het geloof voeding ontvangen tot het oefenen van geduld in aanhoren, onderricht geven, toestemmen, wederleggen, tegenspreken en vermanen.

Want als het bezwaarschrift nu eens niet „uit de Heilige Geest” is? Maar uiting is van wrevel, malcontenterij, ongeestelijk wroeten, zucht tot gelijk willen hebben? Als het bezwaarschrift nu eens "uit de duivel" is, die de twist in de kerken aanblaast? Nu, wat dan nog? Ontslaat zulks een kerkeraad van behandeling der aan de orde gestelde zaken?

Naar onze overtuiging geenszins. Ook in zulk geval zal de bezwaarschriftenschrijver als lidmat van Christus serieus genomen moeten worden. Dan zal hij uit de mond van de gereformeerde ouderling vernemen, dat een lidmaat van Christus bezig is samen te spannen met de grote vijand van Christus. Dan zal die duivel „gescholden" moeten worden. Dat kan een gereformeerde kerkeraad toch nog wel? Ook dát is het volle pond, waarop de bezwaarde recht heeft, tot zijn behoud.

Wanneer het waar is, zoals de bekende uitdrukking zegt, dat Calvijn de paus schaakmat gezet heeft, toen hij de pion van de gereformeerde ouderling naar voren schoof - dan zal diezelfde pion vandaag nog in staat zijn de duivel in de kerk te ontmaskeren. Zo zal de duivel merken, dat hij het heeft gewaagd met de kerk van Christus de strijd te openen. De functionering van de gereformeerde ouderlingschap blijft de kern van de zaak.

Wanneer de geest der profetie iemand dringt bezwaard te zijn, dan ontvangt een lidmaat van de kerk een hoge, zware roeping. Want de tijd van de bezwaarnis is een uitermate zware en gevaarlijke tijd - het pad van de bezwaarde is steil en door vele gevaren omringd. Tot waarachtige, geestelijke, bezwaarnis is waarlijk niet ieder in staat. Een bezwaarde moet zichzelf recht kennen en vooral zijn Heere. Diens Woord en Diens kerk liefhebben.

Want het ,niet-voor-vast-en-bondig-houden" in de zin van artikel 31 K.O. is een geoorloofde vaart en niet zonder kompas. Maar de stuurman van de grote vaart maakt maar al te graag gebruik van uitgezette bakens, die de route markeren, het schip voor stranding op de zandbanken bewaren als het op het secure werk aankomt, dat nodig is om het schip veilig binnengaats te krijgen. „Niet-voor-vast-en-bondig-houden” betekent, dat de door de kerkelijke vergadering gewezen route niet wordt geaccepteerd; men vaart niet langer op de bakens van de kerkelijke uitspraken. Dat mag - soms moet het zelfs. 
Maar het is gevaarlijk, vooral bij stormtij en zware golfslag. Dan moet de wacht verdubbeld, de kaart uitstekend gekend, het kompas zonder onderbreking scherp waargenomen worden. Want in een tijd van bezwaarnis zijn er de geladen energieën van de vleselijke driften. De drift van de toornigheid, van het prestige, van het gelijk-willen-hebben, van het niet meer naar een ander willen luisteren. Er is de verleiding van partijschap, de lokstem van het sectarisme, de woeling van de zelflicfde, de camouflage van het zoeken van eigen "recht" onder de naam van het recht des Heeren.

Hoeveel zelfbeheersing, hoeveel waarachtige liefde tot de kerkeraad, de broeders en zusters, de samenleving der kerken, hoeveel geestelijk verstaan in een tijd van bezwaarnis! Dit zijn toch allemaal elementen van een „ethiek" en "techniek" van bezwaard-zijn naar schriftuurlijke normen. Wie meent dat de zaak gezond is, zodra met het vlaggetje van artikel 31 is gezwaaid, moet maar nooit aan een bezwaarschrift beginnen!

Dárom noemden wij "bezwaarnis" in de kerk een zeer zware en hoge roeping. Slechts de beste stuurlui zijn er toe in staat: de anderen stranden en bereiken nimmer de haven hunner begeerte. Soms lijden zij wel eens schipbreuk, terzake van hun geloof en liefde.

Mochten alle bezwaarde personen en vergaderingen dit al scherper gaan beseffen, we zouden verlost zijn van het kwalijke gebruik van artikel 31 K.O., waarbij dit artikel moet fungeren als een machtswoord, waarmede men - als in een tussenzin - besluiten van kerkelijke vergaderingen kan negeren en frustreren en een schijn van recht verleent aan het niet geduldig willen luisteren naar wat kerkelijke vergaderingen te zeggen hebben. Artikel 31 K.O. is er niet om als een machtswoord te worden gebruikt. Zodanig gebruik teistert soms als een epidemie de kerkelijke samenleving. Maar vast blijft staan: Artikel 31 is een artikel, dat tot een dusdanige zware ambtsoefening roept, dat men wel geneigd zou zijn te vragen: Wie is tot het rechte bezwaardzijn in staat?

\author{
Dr. L. Roeleveld, \\ Senior lektor regte, Universiteit van Durban-Westville.
}

1 Ontleend aan P. Deddens: De ratificering der besluiten van meerdere vergaderingen, Kampen, 1946, blz. 27, noot 57.

2 Ontleend aan Gereformeerd Gezinsblad, 15e jaargang, nr. 1894, Vrijdag 5 December 1958.

3 De betrokken zendeling stelde tegen de kerk een eis in tot betaling van achterstallig salaris, stellende dat de synode zijn schorsing en afzetting als onrechtmatig had veroordeeld. De Rechtbank van Zwolle wees op 16 Maart 1966, Nederlandse Jurisprudentie 1967, no. 178, deze eis af op grond van een uitspraak van de latere synode van Rotterdam-Delfshaven 1964 1965 dat in dit geval een daad van beide partijen, nl. van kerkeraad en van zendeling nodig was om tot ambtsherstel te komen en dat de verhouding tussen hen dus niet kan geacht worden nimmer verbroken te zijn geweest. Een voorbeeld van terzijde stelling van de schorsing van een predikant is de uitspraak van het Hooggeregshof van Suid-Afrika in Smith versus Ring van Keetmanshoop van die N.G. Kerk, Suid-Afrikaanse Hofverslae (1971 (3) bl, 353-365. Het Hof nam aan dat onregelmatigheid in de kerkelijke procedure de predikant benadeeld had. 
4 Mr. J. ter Heide: Kort begrip van Romeins Recht, 1967, Agon Elsevier, blz. 143/144.

5 Volgens het Kanonieke Recht geld de regel „ecclesia vivit secundum legem romanam", welke regel na de Reformatie niet is afgeschaft (prof. mr. A. S. de Blécourt: Kort Begrip van het Oud-Vaderlandsch Burgerlijk Recht, derde druk, blz. 28/29 en 27). De directe binding van de kerk door de meerdere vergadering steunt vooral op de credentiebrief volgens art. 33 K.O. In oude teksten wordt dit soms nog duidelijker uitgedrukt dan tegenwoordig het geval is. Zo luidt een dergelijke brief uit 1620 o.a. „Belovende alles wat in overeenkomstigheid als boven door dezelve hun waarde en lieve broeders gedaan zal worden, goed en vast te houden en gewillig na te komen, even of wij zelf alle tegenwoordig waren geweest" (Zie dr. F. L. Bos: De Orde der Kerk, 1950, 's-Gravenhage, blz. 133/134). Vergelijk hiermede Simon van Leeuwen: Het Rooms-Hollands Regt, 1676, IV boek, XXVI, 4: Algemeene Lastgeving is wederom enkel, daar bij alleenlijk gelast werd het waarnemen van alle des Last-gevers saken..., ofte met de bygevougde clausule, om in alle sijne saken vryelijk te handelen, ende alles te doen, wes den Last-gever tegenwoordig zijnde, zoude kunnen, ofte moge doen.

6 Het bestaan van ratificatierecht werd door $P$. Deddens in zijn genoemde oratie verdedigd. Eveneens in zijn brochure Eerste- en Tweede Hands gezag, Groningen (zonder jaar). Dit standpunt heeft mogelijk aanleiding gegeven tot independentistische tendenzen in de vrijgemaakte Gereformeerde Kerken in Nederland. Hiertegen is opgekomen door J. Kamphuis in Kerkelijke Besluitvaardigheid, Groningen, 1970, blz. 55-65. De predikant D. Deddens heeft in zijn recensie van laatstgenoemde brochure in het Ned. Dagblad van $12 \mathrm{Mei} 1971$ in dit opzicht ook tegen de opvatting van zijn overleden vader gekozen.

7 Volgens P. Deddens t.a.p. pag. 20 heeft de letterlijke tekst van art. 31 K.O. in de redactie van 1619 in tegenstelling tot die van 1581 slechts op appèlzaken betrekking. In deze exclusieve zin wil het artikel zijns inziens echter niet verstaan worden, doch in een algemene zin. De Afrikaanse tekst vertoont terecht m.i. deze laatste algemene betekenis. Dit behoeft echter niet als een afwijking van de K.O. van 1619 beschouwd te worden, indien men aanneemt dat hetzelfde grondbeginsel reeds volgt uit de Schrift, art. 7 en 32 Ned. Geloofsbelijdenis en het Romeinse recht.

8 P. Deddens: t.a.p., blz. 12; J. Hovius: Het verband tussen onze Belijdenis en onze Kerkorde, rede 9 Oktober 1962, Apeldoorn, Sneek, blz. 25. Ook volgens Romeins recht geldt dit: Gaius: Institutiones Lib II Tit IX, par. 20: Sed is, qui mandatur, mandati formam egredi non potest: aut si egressus fuerit, et mandatori teneatur obnoxius, et quod extra mandatum egit, non praejudicet mandatori. Justinianus, Corpus Juris, Institutiones Lib III De mandato par. 8: Is, qui exequitur mandatum 5), non debet excedere fines mandati... alioquin non habebis cum eo mandati actionem. 5) Vinnius MDCCLIV Nam qui excedit, aliud quid facere videtur. Digesten Lib III Tit III, 60: Mandato generali non contineri etiam transactionem, decidendi causa interpositam: et ideo si postea is, qui mandavit, transactionem ratum non habuit, non posse eum repelli ab actionibus exercendis. In dit citaat komt ratum habere m.i. in dezelfde betekenis voor als in art. 31 K.O. 
Johannis Voet, Commentarius ad Pandectas MDCXCVIII Lib XVII Tit I, 6: Mandantur negotia honesta et licita: rei enim turpis nullum est mandatum nec inde inter mandantem et mandatarium actio datur. In zo 'n geval is er dus van nietigheid sprake. Zelfde opvatting bij Simonis van Leeuwen: Censura Forensis 1741 Pars Prima, Lib. IV Cap XXIV Mandari possunt omnes res, omnia facta, modo sint honesta, et licita... Rei turpis et prohibitae mandatum nullum est, nec ex mandato competit actio. 7. nisi quod ad poenam infligendam obligatorium sit... Dit voorbehoud „nisi etc" heeft dus betrekking op een nietige handeling, die niettemin strafwaardig is. Zo kan naar analogie een nietige handeling volgens art. 31 K.O. wel aanleiding zijn voor kerkelijke vermaning en tucht.

Antonius Schultingius, Jurisprudentia vetus Ante-Justinianea Lipsiae MDCCXXXVII, blz. 175: Diligenter enim fines mandati custodiendi sunt.

9 Deze terminologie gebruikt Kamphuis m.i. ten onrechte t.a.p. blz. 56.

$10 \mathrm{Vgl}$. o.a. Acta 1940-1943 Generale Synode Gereformeerde Kerken in Nederland, pag. 270/271: Brief van deze synode aan de kerk van Houwerzijl „Het kerkelijk samenleven laat wel toe, dat een kerk kerkrechtelijke bezwaren heeft tegen genoemde synodale besluiten, en ook, dat ze deze op een volgende generale synode indient; maar niet, dat men deze besluiten vooralsnog niet als bindend aanvaardt; veeleer is zulk een kerk intusschen bij behoud van haar bezwaar, tot de facto-als-bindend-aanvaarden verplicht".

11 Handleiding by die Kerkorde, Potchefstroom 1966, blz. 196: „Gestel egter die skynbaar onskriftuurlike maar gewetensbindende besluit is deur ' $n$ nasionale sinode geneem, moet dit regtelik (de jure) as vas en bindend beskou word, maar die praktiese uitvoering (de facto) dan opgeskort word, terwyl 'n beswaar opnuut langs die kerklike weg aangevoer moet word"; blz. 203/204: „Wanneer die appèl slaag, is die besluit van die mindere vergadering, waarteen geappelleer is, deur die uitspraak van die meerdere vergadering metterdaad kragtens art. 31 K.O. vernietig".

12 Over deze kwestie sprak de burgerlijke rechter zich uit 0.a. in die volgende zaken: Gerechtshof Leeuwarden, 30 October 1946, Nederlandse Jurisprudentie 1947, no. 242, kerk Harlingen: „Het is a priori duidelijk, dat het in art. 31 K.O. gevorderde bewijs bezwaarlijk kan worden geleverd tegenover de Synode, van wie de Besluiten uitgaan en welke sinds 1943 die Besluiten gehandhaafd, de naleving ervan vordert en niet-naleving met schorsing en excommunicatie vervolgt". Gerechtshof Leeuwarden, 23 April 1947, Nederlandse Jurisprudentie 23 Januari 1948, N.J. 1948, no. 433, kerk Ureterp: „Al moge de Generale Synode als het orgaan bij uitnemendheid worden beschouwd, hetwelk over dogmatische vraagstukken in de Kerk in laatste instantie beslist, al moge het ondertekeningsformulier inhouden, dat de ouderlingen en diakenen beloven, dat zij in geval het zou mogen gebeuren, dat zij eenige bedenking tegen de Leer der Kerk kregen, zulks, eer zij het openbaren, het aan den Kerkeraad bekend zullen maken en zich aan het oordeel van den Kerkeraad, Classis en (de Afrikaanse tekst heeft ten onrechte: of, L.R.) Synode zullen onderwerpen, toch de meerderheid van den kerkeraad door stelling te nemen tegen de door de Synode gehuldigde leerstukken en door verder een van de Synode afwijkende leer te openbaren, zonder meer niet verplicht was, als hebbende zij haar regeermacht misbruikt (gelijk door de synodale 
partij bij pleidooi in appèl is betoogd) haar ambt neer te leggen noch van rechtswege haar ambt heeft verloren, zoodat zij geen deel meer van de plaatselijke kerk uitmaakt, daar zulks niet in de K.O. is voorgeschreven, doch integendeel daaruit blijkt, dat op hen die zich in de leer misgaan allereerst de in de K.O. vermelde tuchtprocedure moet worden in werking gesteld.

Gerechtshof Amsterdam 24 Juni 1948 Nederlandse Jurisprudentie 1948, no. 569, kerk Eemdijk: „Uit het besluit van den kerkeraad tot onttrekking uit het verband blijkt dat dit gemotiveerd werd met het feit, dat de meerbesproken leeruitspraak van de Generale Synode uitdrukkelijk is gesteld tot toetssteen der ware leer, waaraan de conscientien der ambtsdragers gebonden werden, zodat zij niets mogen leren, wat met deze uitspraak niet in volle overeenstemming is en van het ambt worden geweerd, indien zij deze binding niet kunnen aanvaarden, en voorts met de omstandigheid, dat door de besluiten der laatstgehouden vergaderingen der Generale Synode in het ambt zijn geschorst, daarvan afgezet en daaruit geweerd broeders, die zich in leer en leven geenszins deze maatregelen waardig hebben gemaakt en waardoor deze Synode in kennelijke strijd is gekomen met de letter en de geest der D.K.O., stellende de Synode de binding aan de leeruitspraken on besluiten der Generale Synode boven de binding aan Gods Woord, de Belijdenis en de D.K.O.; dat de kerkeraad daarmede uitdrukkelijk gesteld heeft dat het slot van art. 31 K.O. van toepassing was... Het bewijzen van het slot van art. 31 K.O. zal in ieder geval niet voor de Rechtbank kunnen geschieden, daar deze niet in een beoordeling van deze geheel op theologisch en kerkelijk gebied liggende vraag mag treden. De kerkeraad moet zelf beoordelen of dit geval zich voordoet. Gerechtshof 's-Gravenhage 28 November 1958, Nederlandse Jurisprudentie 1960, no. 7 betreffende conflict Gereformeerde Gemeente Berkenwoude: Het Hof stelt vast, dat de Dordtse Kerkenordening, vastgesteld door de Nationale Synode van Dordrecht in 1619, zoals die als accoord van kerkelijke gemeenschap is vastgelegd en uitgegeven namens de Gereformeerde Gemeenten in Nederland door ds. G. H. Kersten, gold. Eveneens dat de opvattingen omtrent gereformeerd kerkrecht in het bijzonder uit de 17e eeuw gezag hebben. In de kerkorde wordt niet duidelijk bepaald wie moet beoordelen of strijd tegen het Woord Gods en bedoelde artikelen bewezen is. Het Hof beslist met beroep op art. 84 K.O. - ondanks beroep door tegenpartij op art. 36 K.O. - en Voetius, Politica Ecclesiastica Pars III Lib I Tract III Cap V par 2 sub VI en Cap II par 3 sub 1; voorts de Savornin Lohman-Rutgers, De Rechtsbevoegdheid onzer plaatselijke kerken, 1887, p. 35 en H. Bouwman, Gereformeerd Kerkrecht steeds gehoorzaamheid aan Gods Woord en het geweten is gesteld boven gehoorzaamheid aan besluiten van synoden enz. en voorts dat onder bepaalde omstandigheden als uiterste middel de losmaking van het verband mogelijk is, ja zelfs geboden kan zijn. De kerkeraad die volgens art. 11 K.O. de plaatselijke kerk vertegenwoordigd is hiertoe bevoegd.

13 Gerechtshof Leeuwarden 11 Februari 1948, Nederlandse Jurisprudentie 1949 no. 23 wees de eis tot ontruiming van een pastorie af omdat de schorsing van de gereformeerde predikant van Opende nietig was wegens niet inachtneming van de voorschriften van de K.O. In appèl overwoog het Hof, "dat de geschorste predikant van het schorsingsbesluit van de 
gecombineerde vergadering niet ingevolge art. 31 K.O. heeft geappelleerd, behoeft niet te verhinderen, dat aan dit besluit op grond van daaraan in verband met de K.O. klevende gebreken... rechtsgeldigheid moet worden ontzegd en zulks hier het geval is". Zie ook de zaken, vermeld in de vorige noot. Onjuist is daarom het vermelde op blz. 197 Handleiding by die Kerkorde: „dit is vanselfsprekend dat die bewys ook weer in 'n ooreenstemmende of breër vergadering in die kerkverband gelewer moet word etc." Dit is geen regel zonder uitzondering.

14 Dr. C. Trimp, Gereformeerd Kerkblad voor Zuid-Holland 2 Februarie 1963. 